\title{
STUDY AND COMPARISON OF EMISSION CHARACTERISTICS OF n- butanol / DIESEL BLEND IN CI ENGINE
}

\author{
Atam Parkash Papreja ${ }^{1}$, S K Mahla ${ }^{2}$ \\ ${ }^{1}$ Research Scholar, Shrivenkateshwara University, Gajraula, Uttar Pradesh, India \\ ${ }^{2}$ Director-Principal, Adesh Institute of Engineering and Technology, Punjab, India
}

\begin{abstract}
A lot of emphasis is being laid on the use of biodegradable fuel directly or in blends with diesel to control harmful exhaust emissions and to help environment by reducing global warming in addition to reducing dependence on import of fossil fuels. An experimental study was conducted to study and compare the emission characteristics of n-butanol/diesel blend and diesel. The experiment was conducted on single cylinder, four stroke kirloskar diesel engine with different blends of $n$-butanol/diesel blends. The exhaust emissions of $\mathrm{HC}, \mathrm{CO}, \mathrm{CO}_{2}$ and $\mathrm{O}_{2}$ were measured with Neptune make analyzer.
\end{abstract}

Keywords: $\mathrm{HC}, \mathrm{CO}, \mathrm{CO}_{2}$ and $\mathrm{O}_{2}$

\section{INTRODUCTION}

India of late is emerging as one of the fast growing developing country with an annual growth of $7-8 \%$ with great emphasis on make in India whose campaigning is being spearheaded by the honorable Prime Minister of India. This is possible only if we achieve overall growth in the basic infrastructure i.e. industrialization particularly in manufacturing sector which will in turn require strong national network of transportation for the movement of goods. Recently the honorable Railway Minister has announced use of 5\% diesel fuel blended with biodiesel in the railways which is the largest consumer of petro diesel in India. Though the difference in the cost of biodiesel and diesel is approximately Rs.7, but the biggest advantage of using biodiesel blend is its reduced pollutant emission, reduction in import of fossil fuel thereby saving in prestigious foreign exchange and increased opportunities for the farmers towards production of biodegradable produce required for production of biodiesel. The largest consumer of diesel is the transport sector (rail, air, surface and ships etc) but however the biggest disadvantages of diesel engines being used in transport sectors is of emitting large amount of particulate matter (PM) due to its heterogeneous combustion [3].

After going through extensive technical review of research papers, it has been fairly recognized that addition of oxygenated blend component to diesel fuel result in lower emission of particulate matter and smoke opacity under various operating Conditions [3]. Two bio fuels which have been found to be widely used are biodiesel and bio-ethanol for diesel and petrol engines, respectively [2]. Traditionally bio-alcohols have been used in spark ignition engines but however of late they are being considered for blending with diesel in various blends and ethanol because of its renewable origin i.e. sugar cane, corn or using lignocelluloses biomass has found favors with various researchers because of its oxygen content which reduces smoke opacity and PM [2].
Recent researches in exploring use of other alcohols have led them to believe that in the time to come butanol will be a major competitor to ethanol for using as blend with diesel though a lot of work has to be done. The major factors that go in its favors are higher heating value, higher cetane number and less volatile than ethanol and methanol [2]. Miscibility of butanol with diesel better than ethanol, potential to overcome the drawback brought about by lowcarbon alcohol and blending with diesel without phase separation and the energy content of n-butanol fuel (28.4 $\mathrm{MJ} / \mathrm{L})$ better than that of ethanol $(21.2 \mathrm{MJ} / \mathrm{L})$ and moreover ethanol has not been found suitable in compression ignition engine has made $n$-butanol the most preferable and formidable choice of researchers and manufactures in the world [4]. Though lots of researchers have carried out investigation of performance and emission characteristics of n-butanol/diesel blend on CI engines but fewer reports are available. In this experimental investigation, an attempt has been made to study and compare emission characteristics of n-butanol/diesel blend on CI engine.

Table $1 \mathrm{n}$-Butanol/diesel mixture ratio by volume

\begin{tabular}{|l|l|l|l|}
\hline Blend & $\begin{array}{l}\text { n-butanol } \\
(\%)\end{array}$ & Diesel (\%) & Identification \\
\hline 1 & 0 & 100 & B0 \\
\hline 2 & 5 & 95 & B5 \\
\hline 3 & 10 & 90 & B10 \\
\hline 4 & 15 & 85 & B15 \\
\hline 5 & 20 & 80 & B20 \\
\hline
\end{tabular}

\section{EXPERIMENTAL SET UP}

The experiments were performed on kirloskar oil engine ltd. single cylinder, four stroke engines model EA10G1 (Bore*stroke-102*116 $\mathrm{mm}^{2}$ ) and emission characteristic were measured using NEPTUNE analyzer model HG-540 for measurement of $\mathrm{CO}, \mathrm{HC}, \mathrm{CO}_{2}$ and $\mathrm{O}_{2}$ 
Table 2 Experimental results

\begin{tabular}{|c|c|c|c|c|}
\hline Load & \multicolumn{4}{|c|}{30} \\
\hline & $\mathrm{HC}$ & $\mathrm{CO}$ & $\mathrm{CO}_{2}$ & $\mathrm{O}_{2}$ \\
\hline B0 & 76 & 0.42 & 4.59 & 14.15 \\
\hline B5 & 74 & 0.38 & 4.40 & 14.98 \\
\hline B10 & 67 & 0.23 & 4.27 & 15.01 \\
\hline B15 & 64 & 0.24 & 4.19 & 15.45 \\
\hline B20 & 62 & 0.23 & 4.11 & 15.80 \\
\hline
\end{tabular}

Table 3 Experimental results

\begin{tabular}{|l|l|l|l|l|}
\hline $\begin{array}{l}\text { Load } \\
\text { \%lend }\end{array}$ & \multicolumn{4}{l|}{} \\
\hline & $\mathrm{HC}$ & $\mathrm{CO}$ & $\mathrm{CO}_{2}$ & $\mathrm{O}_{2}$ \\
\hline B0 & 102 & 0.68 & 9.15 & 10.16 \\
\hline B5 & 102 & 0.52 & 9.58 & 10.56 \\
\hline B10 & 96 & 0.41 & 10.11 & 11.23 \\
\hline B15 & 86 & 0.41 & 10.02 & 11.37 \\
\hline B20 & 82 & 0.38 & 9.56 & 11.56 \\
\hline
\end{tabular}

Table 4 Experimental results

\begin{tabular}{|l|l|l|l|l|}
\hline $\begin{array}{l}\text { Load } \\
\text { Blend }\end{array}$ & \multicolumn{4}{|l|}{90} \\
\hline & $\mathrm{HC}$ & $\mathrm{CO}$ & $\mathrm{CO}_{2}$ & $\mathrm{O}_{2}$ \\
\hline B0 & 118 & 2.16 & 12.26 & 7.56 \\
\hline B5 & 115 & 2.05 & 11.48 & 7.68 \\
\hline B10 & 113 & 1.88 & 11.12 & 8.02 \\
\hline B15 & 112 & 1.80 & 10.80 & 8.75 \\
\hline B20 & 102 & 1.82 & 10.62 & 9.10 \\
\hline
\end{tabular}

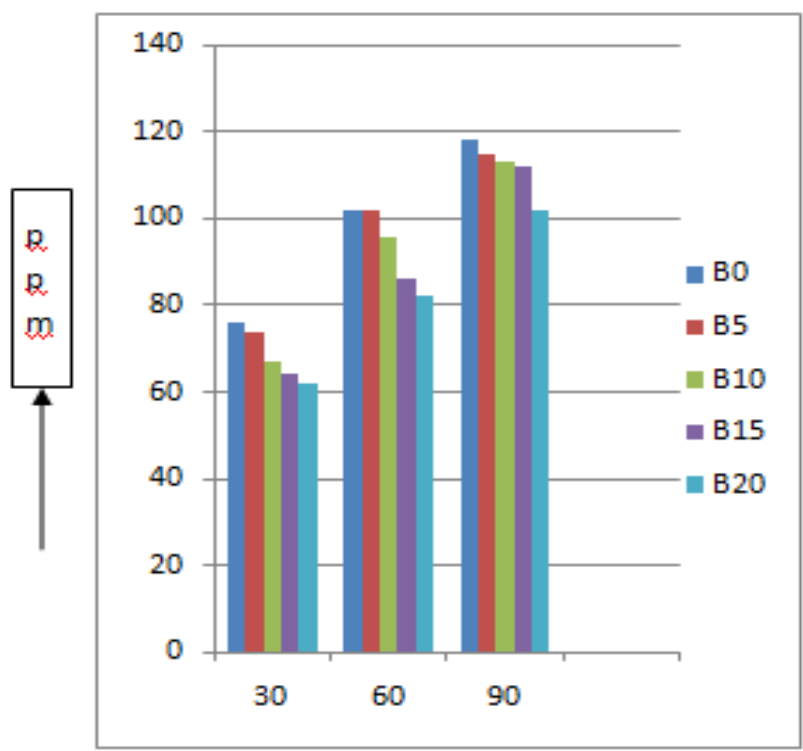

Load Percentage

Fig 1 HC VS LOAD

\section{RESULTS AND DISCUSSIONS}

Hydrocarbon, HC: Figure 1 show HC emissions, which are caused by incomplete combustion of fuel, of $\mathrm{n}$ butanol/diesel blends are lesser at all loads than diesel (B0). However they are less significant at full load probably because of lower cetane value. Reduction in $\mathrm{HC}$ emissions in n-butanol/diesel blends are caused by higher oxygen content.

Carbon monoxide, CO: $\mathrm{CO}$ emissions are also the result of incomplete or bad combustion. Though they do not create smog but are very deadly as it hurts human being. Therefore their controls are mandated strictly and figure 2 shows lesser $\mathrm{CO}$ emissions in $\mathrm{n}$-butanol/diesel blends than diesel because of oxygenated fuel. It also shows that as the concentration of $\mathrm{n}$-butanol is increased beyond $10 \%$, reductions of CO emissions are non-significant because of lower cetane and heating value. Higher $\mathrm{CO}$ emissions were observed at nearly full load.

Carbon dioxide, CO2: Though emissions of $\mathrm{CO} 2$ are good as they are liked by plants and vegetable and do not hurt us but of late has become a major concern for global warming. Emissions of $\mathrm{CO} 2$ are lesser in n-butanol/diesel blends than diesel at nearly full load as is evident in figure 3. This justifies use of blended fuel in transport sector to emit fewer $\mathrm{CO} 2$ gases to help control global warming.

Oxygen, O2: Figure 4 shows higher emission of oxygen in n-butanol/diesel blends than diesel which authenticates our claim that blending of diesel with biodegradable fuel enhances oxygen content and helps in achieving complete combustion thereby limiting harmful emissions and that is why they are termed as oxygenated fuels.

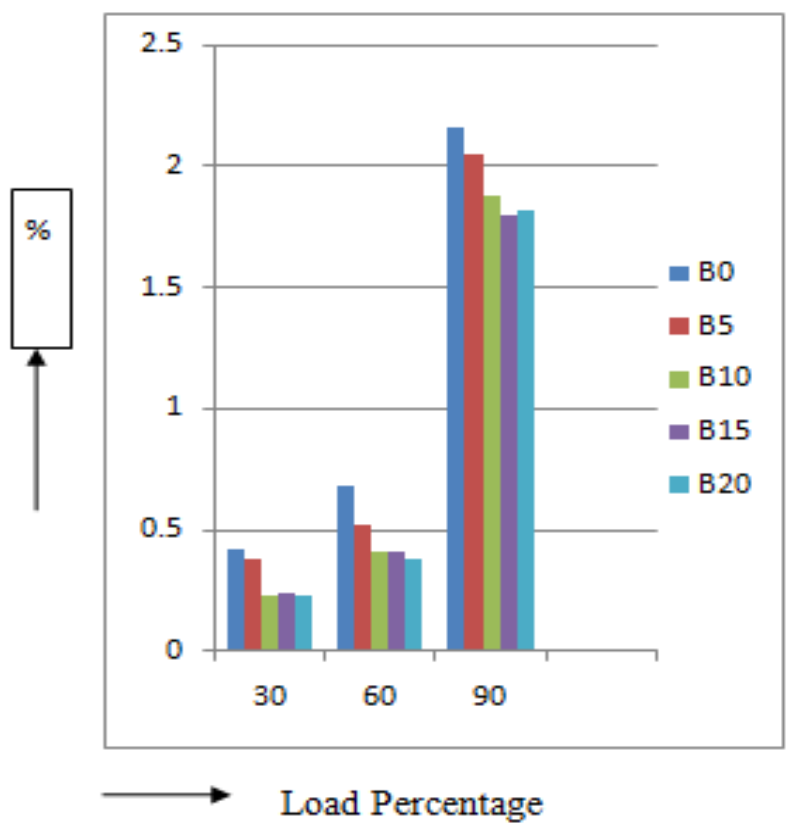

Fig 2 CO VS LOAD 


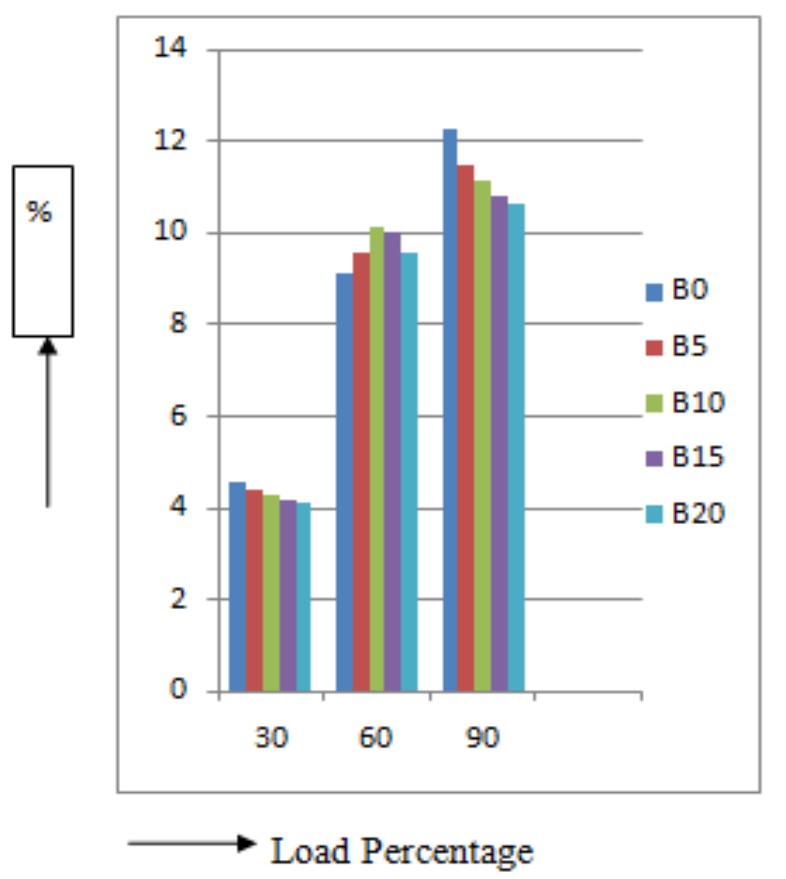

Fig $3 \mathrm{CO}_{2}$ VS LOAD

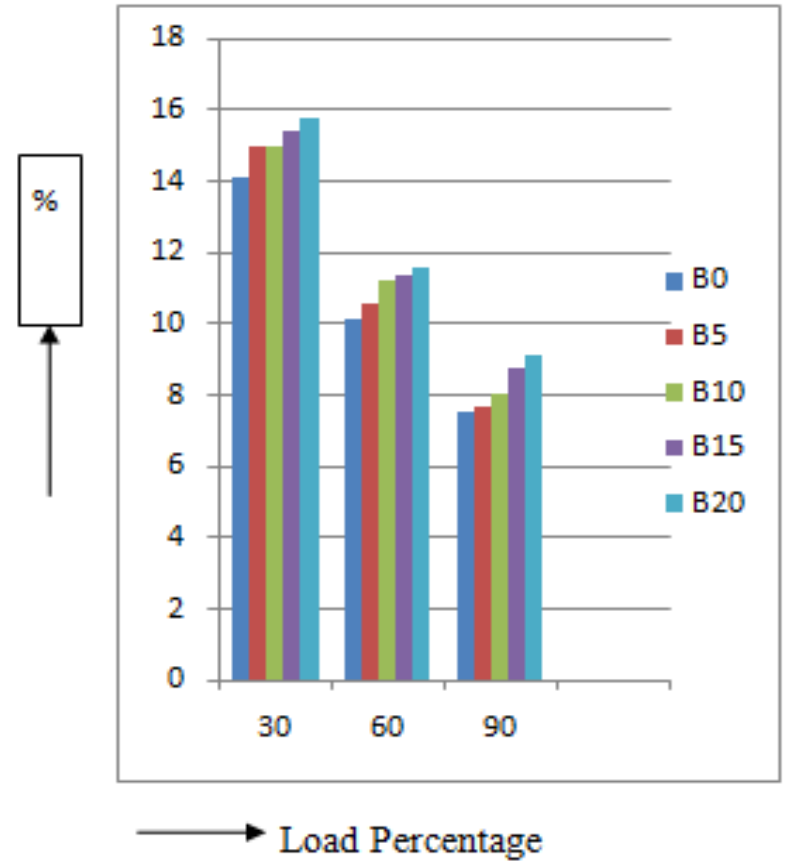

Fig $4 \mathrm{O}_{2}$ VS LOAD

\section{CONCLUSION}

The experiment was conducted to study the effects of varying n-butanol/diesel blends (B0, B5.B10, B15 and B20) on exhaust emissions and the following conclusions were drawn:

$>$ Though n-butanol has lower cetane value but its blending with diesel has helped considerably in reducing emissions of $\mathrm{HC}$ and $\mathrm{CO}$.

$>\mathrm{N}$-butanol/diesel blends have produced encouraging results of emitting lower $\mathrm{CO} 2$ which is extremely essential to prevent global warming.

\section{REFERENCES}

[1]. Benjamin r. Wigg "A study on the emissions of butanol using a spark ignition engine and their reduction using electrostatic ally assisted injection"

[2]. Octavio Armas, Reyes Garcia-Contreras and Angel Ramos "Pollutant emissions from engine starting with ethanol and butanol diesel blends"

[3]. T.Krishnaswamy and N. Shenbaga Vinayaga Moorthi, "Performance evaluation of diesel engine with oxygenated bio-fuel blends" Vol.7, No.1, January2012, ARPN journal of Engineering and Applied Science.

[4]. Lennox Siwale, Lukacs Kristof, Torok Adam, Akos Bereczky, Makame Mbarawa, Antal Penninger and Andrei Kolesnikov," Combustion and emission characteristics of nbutalol/diesel blend in a turbo-charged compression ignition engine. 